\title{
Correction: Metrics for the sustainable development goals: renewable energy and transportation
}

Jonathan J. Buonocore, Ernani Choma, Aleyda H. Villavicencio, John D. Spengler, Dinah A. Koehler, John S. Evans, Jos Lelieveld (1), Piet Klop \& Ramon Sanchez-Pina

Correction to: Palgrave Communications https://doi.org/10.1057/s41599-019-0336-4, published online 12 November 2019.

The original version of this Article contained an error in Fig. 1.

The units label for the axis on panel 3 should read "Tons $\mathrm{CO} 2 /$ toe" rather than "Thousand tons $\mathrm{CO} 2 /$ toe". The text describing that panel should read "Tons $\mathrm{CO} 2 /$ toe" rather than "kg CO2".

This has now been corrected in both the PDF and HTML versions of the Article.

Published online: 26 November 2019

\footnotetext{
(c) (i) Open Access This article is licensed under a Creative Commons Attribution 4.0 International License, which permits use, sharing, adaptation, distribution and reproduction in any medium or format, as long as you give appropriate credit to the original author(s) and the source, provide a link to the Creative Commons license, and indicate if changes were made. The images or other third party material in this article are included in the article's Creative Commons license, unless indicated otherwise in a credit line to the material. If material is not included in the article's Creative Commons license and your intended use is not permitted by statutory regulation or exceeds the permitted use, you will need to obtain permission directly from the copyright holder. To view a copy of this license, visit http://creativecommons.org/licenses/by/4.0/.
}

(C) The Author(s) 2019 


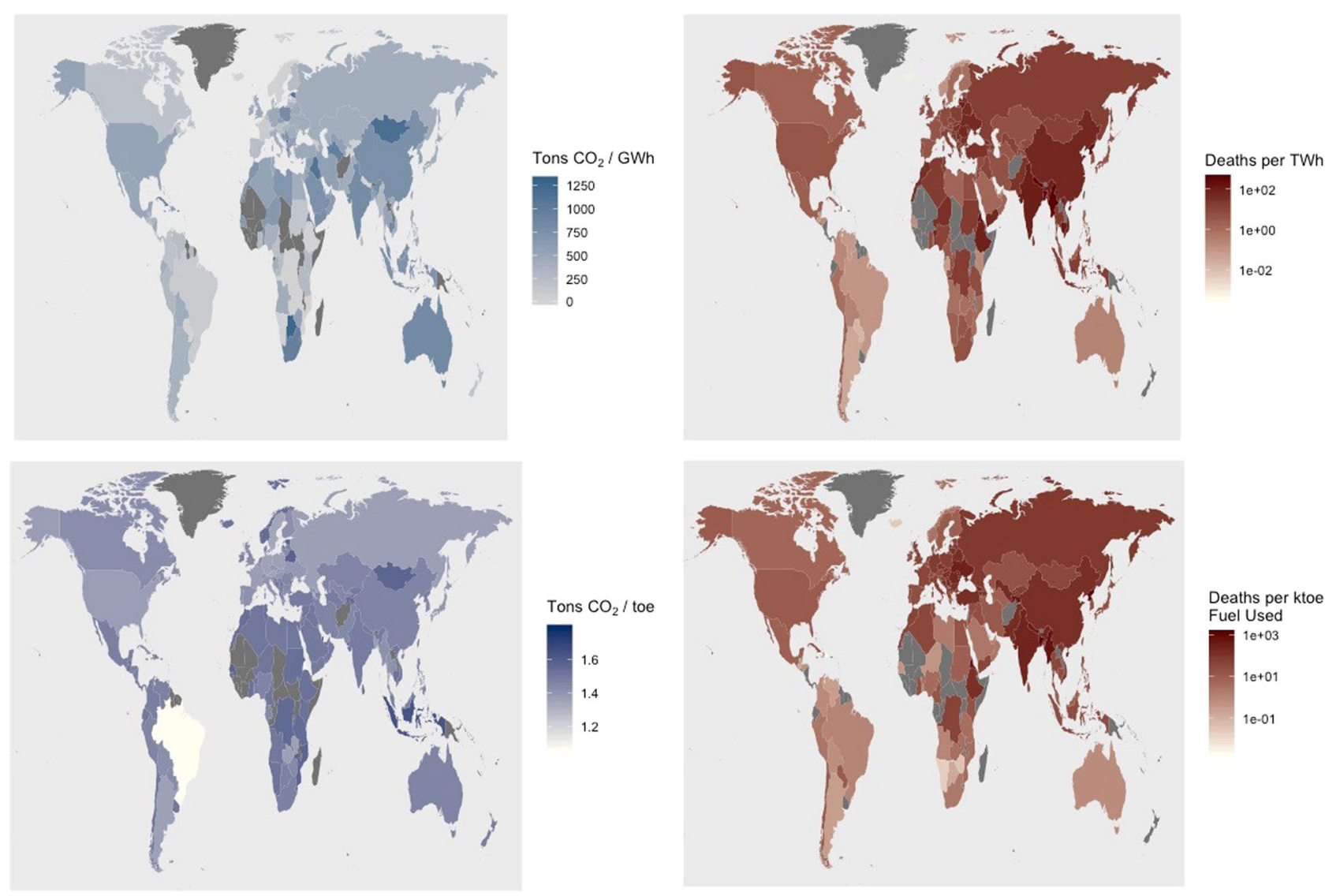

Fig. 1 Carbon dioxide emission rates (Tons per GWh) of each country's electrical grid, health impact rate (excess mortality cases per TWh) of air pollutant emissions from each country's electrical grid, $\mathrm{CO}_{2}$ emissions rate ( $\mathrm{Ton} \mathrm{CO}_{2}$ per ton of oil equivalent) from transportation in each country, and health impact rate (deaths per 1000 tons of oil equivalent consumed) from air pollutants from transportation in each country, in 2010 (International Energy Agency n.d.). Countries in dark grey did not have data available. 